\title{
CAVERNOUS HAEMANGIOMA OF PARAPHARYNGEAL SPACE: A CASE REPORT
}

\author{
Sushil Kumar Kashyap¹, Bhoopendra Singh², Chandra Bhan³, Ajay Pratap Singh ${ }^{4}$, Mohd. Azeem
}

\section{HOW TO CITE THIS ARTICLE:}

Sushil Kumar Kashyap, Bhoopendra Singh, Chandra Bhan, Ajay Pratap Singh, Mohd. Azeem. "Cavernous Haemangioma of Parapharyngeal Space: A Case Report". Journal of Evolution of Medical and Dental Sciences 2015; Vol. 4, Issue 33, April 23; Page: 5763-5767, DOI: 10.14260/jemds/2015/842

ABSTRACT: OBJECTIVE: we are presenting a rare case of cavernous haemangioma of parapharyngeal space. CASE REPORT: 30 years old female presented with two non-reducible, compressible, soft swelling in neck and on posterolateral wall of right side of oropharynx. On examination we found a bluish colour swelling present on oropharynx. USG shows $11 \times 25 \times 32 \mathrm{~mm}$ well defined lesion present on neck along with another soft swelling present in submandibular region. Patient was explained regarding the further investigation and treatment but she did not turn up. CONCLUSION: cavernous haemangioma should be considered in the differential diagnosis of a parapharyngeal mass. It may also extend to anterior triangle of neck.

KEYWORDS: cavernous haemangioma, phayapharyngeal space.

INTRODUCTION: The parapharyngeal space is an inverted pyramidal shaped space. Its base is situated at the base of skull (Petrous part of temporal bone) and apex is at greater cornu of hyoid. It is bounded medially by the lateral wall of the nasopharynx and oropharynx, posterolaterally it is related to the deep lobe of the parotid gland anterolaterally to the ramus of mandible. Inferiorly it descends into the neck medial to the carotid sheath. Posterosuperiorly it communicates with infra temporal fossa. Parapharyngeal space is of special importance for several reasons like complex anatomy, its close proximity to vital anatomical structures and the various complex surgical approaches. Whatever pathological process involves this space there is the potential for spread to the skull base or the upper mediastinum.

Cavernous hemangioma are vascular malformation formed by abnormal dilation of venous blood vessels, gives rise to soft spongy bluish swelling, which is compressible and can be emptied by pressure but reappeare on release of pressure.

We present here a female patient with a cavernous haemangioma of the parapharyngeal space, which had extended into the deep spaces of the neck.

CASE REPORT: A 30-year-old female presented with 2 years history of two small swelling on the right side of the neck and one smooth swelling in throat which are slowly increasing in size. She did not have any other symptoms.

Examination of her oral cavity and oropharynx showed a bluish coloured swelling in right posterolateral pharyngeal wall. Swelling was soft compressible but not reducible (Figure-1). There were two soft swelling in right side of neck one in jugulodiagastric area which was $3 \times 2 \mathrm{~cm}$ in size another in omohyoid area of $4 \times 2 \mathrm{~cm}$ in size. Swellings were compressible, non-pulsatile extending beneath the sternocleidomastoid muscle and no bruit was heard over it (figure-2). No other abnormalities were present on ENT or General examination. She underwent panendoscopy her chest X-ray was clear and the full blood count was normal. 


\section{CASE REPORT}

Fine needle aspiration cytology from the right neck swelling produced a blood aspirate. High resolution USG of neck shows a well- defined $11 \times 25 \times 32 \mathrm{~mm}$ well defined lesion with multiple seprigenous channel in it is seen anterior to right lobe of thyroid medial to right sternoclediomastoid muscle, another swelling seen deep in the right submandibular region at the floor of oral cavity these lesion exhibit flow on CDFI, accentuated by vulsulva maneuver (Figure- 3). Rest structures were normal.

The patient was explained for further investigation and treatment. She did not turn up.

DISCUSSION: The parapharyngeal space is a potential space formed within fascial layers of the lateral upper neck. Its medial boundary is the lateral wall of the pharynx and posterolaterally it is related to the deep lobe of the parotid gland. Inferiorly it descends into the neck medial to the carotid sheath. Postero superiorly it communicates with infra temporal fossa. Various infective and neoplastic disease processes have been reported to occur in the parapharyngeal space.

Primary neoplasms found in the parapharyngeal space may originate from minor salivary gland tissue, the deep lobe of the parotid gland, glomus bodies, lymphoid tissue and nervous tissue. Haemangiomas are hamartomas rather than true neoplasms as they are generally composed of vascular spaces arising from endothelial cells and not by incorporation of nearby vascular channels. Watson and McCarthy[1] reported that $56 \%$ of all haemangiomas were seen to occur in the head and neck region and were noted to be mostly of congenital origin with $85 \%$ seen in newborns and first year infants, in a series of 1363 cases. They are not commonly seen in adults. Cavernous haemangiomas are typically subcutaneous and can occur as a mixed variety with capillary component. The capillary cavernous haemangioma (mixed) is considered more common than the pure cavernous form (Blackfeld).[2] Haemangioma in the parotid gland (Robertson),[3] intramuscular haemangioma (Chatrath) ${ }^{[4]}$ have been reported in the literature. Ueda masarua et al,[5] reported a case of cavernous haemangioma of pharapharyngeal space. Kale US et a) ${ }^{[6]}$ reported, cavernous haemangioma appear as soft, compressible lesions with indistinct boundaries. They may be complicated by infection. Similar behaviour in a case of intramuscular haemangioma over the maxilla presenting as recurrent painful swelling, responding each time to antibiotic, has been reported by (Chatrath et al).[4]

This is in accord with the findings reported by (Rossiter et al)[7], with intramuscular haemangioma where it was found that fine needle aspiration cytology results in misdiagnosis due to an excessively bloody specimen.

The MRI Scan gave an intermediate signal on T1 weighted images with a high signal on T2 and STIR sequences and was more helpful than CT Scanning. This was shown by Itoh et al, ${ }^{[8]}$ whose study reports that MRI clearly demonstrates haemangioma with good contrast between lesion and normal tissues while CT does not allow differentiation between these lesions and the surrounding normal tissues. According to Asperstrand and Kolbenstvedt, ${ }^{[9]}$ MRI is superior to CT and far better than angiography in delineating cavernous haemangiomas. One more interesting radiological investigation to be mentioned here is the role of sonography. Yang et al,[10] mention that when performing sonography on soft tissue masses in the head and neck, the presence of colour Doppler signal in a well-defined hypoechoic mass with heterogeneous echotexture should raise the possibility of a haemangioma. Perfusion and blood pool scintigraphy has been demonstrated to have high sensitivity for detecting head and neck haemangiomas and can also differentiate between cavernous 


\section{CASE REPORT}

and venous haemangioma. (Murata et al,).[11] Doppler sonography could not differentiate between cystic lymphangioma and large-vessel haemangioma. The intravenous echo-enhancing contrast agent Levovist was administered, and a significant echo-enhancing effect on colour and power Doppler imaging was demonstrated (Yi-Hong Chou, et al,).[12]

Cavernous haemangioma in the head and neck region is best treated by complete surgical excision when feasible. (Poe and Blair).[13] Various other treatment options for haemangiomas including systemic steroids (Edgerton),[14] intralesional injections of steroids (Kushner) ${ }^{[15]}$ or sclerosing agents, laser surgery (Waver et al),[16] and ionising radiation (Nordberg and Sandberg) ${ }^{[17]}$ have been reported with variable results. Pre- operative embolisation may reduce the per-operative bleeding. Hashimoto et al,[18] reported that super selective therapeutic embolisation not followed by surgery is the treatment of choice for the vascular lesions of the head and neck. Therapeutic coagulation induced in cavernous haemangiomas by the use of percutaneous copper needles has also been shown to be effective treatment. (Li).[19] In our case there is persisting swelling lateral wall of oropharynx extending in to anterior triangle of neck medial to sternocleidomastoid muscle. USG shows that these swelling exhibit slow flow on CDFI, accentuated by valsulva manoeuvre.

SUMMARY: This case presentation illustrates that cavernous haemangioma should be considered in the differential diagnosis of a parapharyngeal mass. It may extend to anterior triangle of neck. USG with colour Doppler is a useful diagnostic tool, To confirm the diagnosis MRI still provide better delineate than CT, between haemangima and normal tissue.

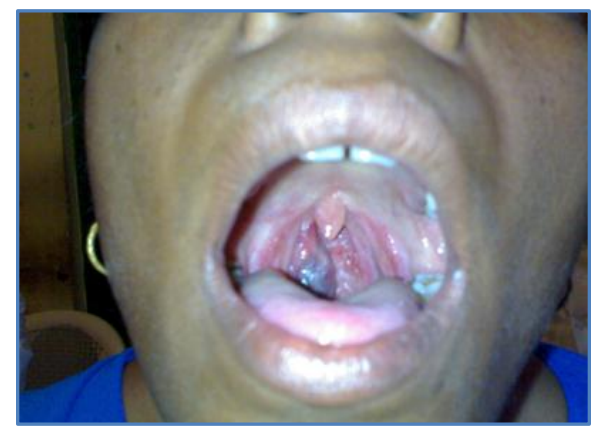

\section{Fig. 1: shows Bluish coloured soft mass present} over Rt. posterolateral oropharyngeal wall

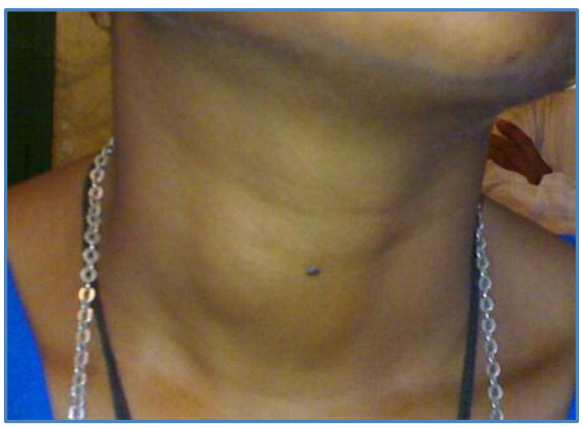

Fig. 2: Swelling present in Rt. anterior triangle of neck 


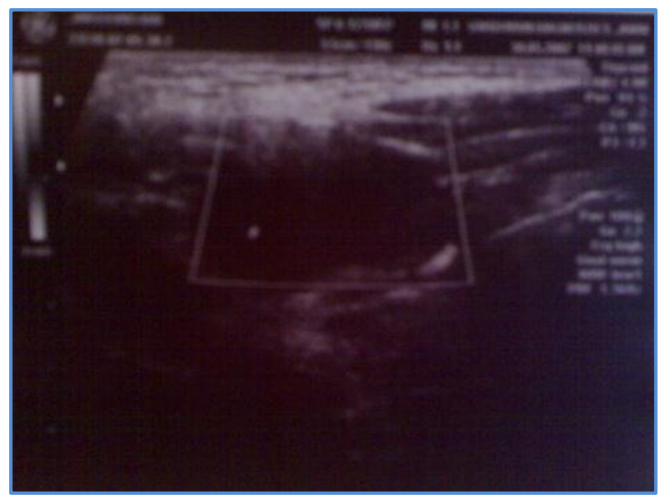

\section{Fig. 3: USG neck shows $11 \times 25 \times 32 \mathrm{~mm}$ well defined} lesion with multiple seprigenous channel in it

\section{REFERENCES:}

1. Watson WL, McCarthy MD. Blood and lymph vessel tumours - A report of 1,056 cases. Surg Gynecol Obstet 1940; 171: 569-88.

2. Blackfield HM, Morris WJ, Torrey FA. Visible haemangiomas: A Preliminary report of a 10-year study. Plast Reconstr Surg 1960; 26: 326.

3. . Robertson JS, Wiegand DA, Schaitkin BM. Life threatening haemangioma arising from the parotid gland. Otolaryngol Head Neck Surg 1991; 104: 858-62.

4. Chatrath P, Pfleiderer AG, Blundell JW. A rare case of intramuscular haemangioma in a six-yearold boy - a diagnostic dilemma. J Laryngol Otol 1998; 112: 1181-2. ]

5. Ueda masarua et al, Case of Cavernous hemangioma in the Parapharyngeal Space. Journal of Otolaryngology - Head and Neck Surgery (Tokyo) 2001; 73: 9; 602-605.

6. U.S. kale et al. Indian journal of otolaryngology and head and neck surgery vol.58, no 1 January march 2006.

7. Rossiter JL, Herdvix RA, Tom LW, Hendrix WC, Postic WP. Intramuscular haemangioma of head and neck. J Otolaryngol Head Neck Surg 1993; 108: 18-26.

8. Itoh K, Nishimura K, Togashi K, Fujisawa I, Nakano Y, Itoh H, et al. MR imaging of cavernous hemangioma of the face and neck. J Comput Assist Tomograph 1986; 10: 831.

9. Aspestrand F, Kolbenstvedt A. Vascular mass lesions and hypervascular tumours in the head and neck. Characteristics at CT, MR Imaging and angiography. Acta Radiologica 1995; 36: 13641.

10. Yang WT, Ahuja A, Metreweli C. Sonographic features of head and neck haemangiomas and vascular malformations: review of 23 patients. J Ultrasound Med 1997; 16: 39-44.

11. Murata Y, Yamada I, Umehara I, Ishii Y, Okada N. Perfusion and blood pool scintigraphy in the evaluation of head and neck haemangiomas. J Nucl Med 1997; 38: 882.

12. Yi-Hong Chou, et al Echo-enhancing sonography of a large-vessel hemangioma of the neck Inc. J Clin Ultrasound 1999; 27: 465-468, 1999.

13. Poe R, Blair PA. Haemangioma of the head and neck. J Louisiana State Med Soc 1987; 139: 1720.

14. Edgerton MT. The treatment of haemangiomas with special reference to the role of steroid therapy. Ann Surg 1976; 183: 517-32. 
15. Kushner BJ. Intra lesional corticosteroid injection for infantile adnexal haemangioma. Am J Ophthalmol 1982; 93: 496-506.

16. Waner M, Sven JY, Dinehart S. Treatment of haemangiomas of the head and neck. Laryngoscope 1992; 102: 1123-34.

17. Nordberg U, Sandberg J. Indications and methods for radiotherapy of cavernous haemangiomas. Acta Radiologica 1962; 1: 257-74.

18. Hashimoto $Y$, Matsuhiro K, Nagaki M, Tanioka H. Therapeutic embolisation for vascular lesions of the head and neck - report of two cases. Int J Oral Maxillofac Surg 1989; 18: 47-9.

19. Li ZP. Therapeutic coagulation induced in cavernous haemangioma by use of percutaneous copper needles. Plast Reconstruct Surg 1992; 89: 613-22.

\section{AUTHORS:}

1. Sushil Kumar Kashyap

2. Bhoopendra Singh

3. Chandra Bhan

4. Ajay Pratap Singh

5. Mohd. Azeem

\section{PARTICULARS OF CONTRIBUTORS:}

1. Associate Professor, Department of ENT \& Head Neck Surgery, M. L. B. Medical College, Jhansi, Uttar Pradesh.

2. Junior Resident, Department of ENT \& Head Neck Surgery, M. L. B. Medical College, Jhansi, Uttar Pradesh.

3. Junior Resident, Department of ENT \& Head Neck Surgery, M. L. B. Medical College, Jhansi, Uttar Pradesh.

\section{FINANCIAL OR OTHER} COMPETING INTERESTS: None
4. Junior Resident, Department of ENT \& Head Neck Surgery, M. L. B. Medical College, Jhansi, Uttar Pradesh.

5. Junior Resident, Department of ENT \& Head Neck Surgery, M. L. B. Medical College, Jhansi, Uttar Pradesh.

\section{NAME ADDRESS EMAIL ID OF THE CORRESPONDING AUTHOR:}

Dr. Sushil Kumar Kashyap,

Associate Professor, Department of ENT \& HEAD Neck Surgery, Flat No. P. R. 19, M. L. B. Medical College, Jhansi, Uttar Pradesh, India. E-mail: sushiled20@gmail.com

Date of Submission: 28/03/2015. Date of Peer Review: 30/03/2015. Date of Acceptance: 11/04/2015. Date of Publishing: 23/04/2015. 